DOI: 10.22591/magyurol.2018.1.kubika.12

\title{
Húgyhólyag-augmentáció: a neurogén hólyagdiszfunkció kezelési lehetősége
}

\author{
Kubik András dr., Keszthelyi Attila dr., Nyirády Péter dr., Majoros Attila dr.
} Semmelweis Egyetem, Urológiai Klinika és Uroonkológiai Centrum, Budapest (igazgató: Nyirády Péter dr.)

\author{
evelezési cim: \\ Dr. Kubik András \\ SE Urológiai Klinika \\ és Uroonkológiai Centrum \\ 1082 Budapest, Üllői út 78/b \\ E-mail: kubikandras@gmail.com
}

\begin{abstract}
ÖSSZEFOGLALÁS
Bevezetés: A neurogén húgyhólyag-diszfunkció kezelése lépcsőzetes, elsővonalbeli kezelésében jelentős szerep jut az intermittáló önkatéterezésnek. Sajnos sok betegnél a húgyhólyag primeren, vagy az állapot progressziója következtében idővel magasnyomásúvá és/vagy csökkent kapacitásúvá, tágulékonyságúvá válik. Amennyiben egyéb kevéssé invazív kezelésekkel (intermittáló katéterezés - CIC), anticholinergicum, botulinum toxin, sphincterotomia) nem sikerül a húgyhólyag nyomását csökkenteni, illetve kapacitását, tágulékonyságát (compliance) növelni, akkor a hólyag kirekesztett bélszakaszszal történő megnagyobbítása (augmentáció) végezhető. A magasnyomású és/vagy kis kapacitású, rossz tágulékonyságú hólyagmüködés okozta reflux, következményes vesekárosodás és recidiv húgyúti fertőzés ezzel végleg megszüntethető.
\end{abstract}

Betegek és módszerek: Klinikánkon egy 23 éves és egy 28 éves nőbetegnél végeztünk neurogén húgyhólyag-diszfunkció miatt nyílt húgyhólyag-augmentációt. Mindkét esetben veleszületett gerincfejlődési rendellenességek (kongenitális sacrum agenesia, illetve meningomyelocele) képezték a neurogén eredetű húgyhólyag müködési zavar alapját. Konzervatív (anticholinergicum + CIC) és minimál invazív (botox intradetrusor injekció) terápia hatástalansága miatt mindkét betegnél kirekesztett ileum szakasszal történő húgyhólyag-augmentáció végzésére kényszerültünk.

Eredmények: A mútéteket követően mindkét beteg kontinenciája javult, a húgyúti fertőzések száma csökkent, húgyhólyagjukat továbbra is intermittáló katéterezéssel ürítik. A kontroll urodinamikai vizsgálat a hólyagkapacitás és compliance szignifikáns növekedését igazolta.

Következtetések: A neurogén húgyhólyag-diszfunkció elsővonalbeli kezelési lehetőségét, sok esetben annak bázisterápiááát az intermittáló önkatéterezés jelenti. Amennyiben konzervatív kezelés segítségével nem sikerül az alacsony nyomású, jó tágulékonyságú és kapacitású hólyagmüködés megtartása, akkor a húgyhólyag bélszakasszal történő augmentációját javasolt elvégezni.

\section{KULCSSZAVAK}

NEUROGÉN HÓLYAGMÜKÖDÉSI ZAVAR, CSÖKKENT HÚGYHÓLYAG COMPLIANCE, HÚGYHÓLYAG-AUGMENTÁCIÓ

\section{Bladder augmentation: a treatment for neurogenic bladder dysfunction}

\section{SUMMARY}

Objective: Treatment of neurogenic bladder dysfunction is staggered, based on intermittent self-catheterization (CIC) in many cases. Unfortunately, over time either primarily or during progression in such cases urinary bladder becomes high pressured, reduced capacitated and expanded. If other minimal invasive treatments (such as clean intermittent catheterisation, anticholinergics, botulinum toxin, sphincterotomy) fail to reduce urinary bladder pressure and increase its capacity, compliance, then augmentation of bladder with excluded ileum section may result a good solution in high pressure reflux, renal impairment and recurrent urinary tract infections causing permanent disease.

Patients and methods: At our clinic, a 23-year-old and a 28-year-old female patient had open bladder augmentation due to neurogenic bladder dysfunction. In both cases, congenital spinal cord disorders (congenital sacrum agenesia or meningomyelocele) formed the basis for neurogenic bladder dysfunction. Conservative (anticholinergicum $+\mathrm{CIC}$ ) and minimal invasive (botox intradetrusor injection) therapy was ineffective; bladder augmentations with excluded ileum sections were performed in both patients.

Results: Following the operation, the patients' continence was improved, the numbers of urinary tract infections were decreased and their urinary bladder was still emptied by intermittent catheterization. The control urodynamic study demonstrated a significant increase in bladder capacity and compliance.

Conclusion: The first-line therapy, in many cases the base therapy for neurogenic bladder dysfunction is intermittent self-catheterization. If the conservative treatment does not manage to maintain low pressure, good compliance and capacity of the bladder, then augmentation of the urinary bladder is recommended with bowel application.

\section{KEYVWORDS}

NEUROGENIC LOWER URINARY TRACT DYSFUNCTION; POOR BLADDER COMPLIANCE, AUGMENTATION ILEOCYSTOPLASTY 


\section{Bevezetés}

A neurogén hólyagdiszfunkció magyar szakirodalomban is megtalálható rövidítése (NLUTD) az angol megfelelőjéből (neurogenic lower urinary tract dysfunction) ered (1). Leginkább veleszületett, vagy szerzett ideggyógyászati betegségek, sérülések következtében alakulnak ki a neurogén eredetű vizelettartási vagy ürítési zavarok, amelyek gyakran kombinálódnak. A vizelettartás és -ürítés normális szabályozásához az ép húgyhólyag és záróizom-apparátus mellett, a sacralis 2-4es gerincvelői szegmentumokban elhelyezkedő intakt vizelési központra, a vizelési inger tudatosulásához szükséges, sértetlen agyi centrumra, illetve a húgyutak és a szabályozó idegi központok közötti érintetlen afferens és efferens idegpálya kapcsolatokra van szükség. Amennyiben ebben a bonyolult és kifinomult rendszerben bárhol hiba keletkezik, az a vizelettartás és -ürítés funkcionális panaszával járhat (2).

A neurogén hólyagfunkció-zavarok felosztása történhet a kiváltó ok szerint, amelyek között megkülönböztetünk veleszületett betegségeket (pl. meningomyelocele), illetve szerzett elváltozásokat (sérülés, tumor, gyulladás, sclerosis multiplex stb). A károsodás elhelyezkedése alapján elkülönítünk felső és alsó motoneuron léziót (FMNL, AMNL), előbbi a sacralis vizelési központ (S2-4) szintje felett elhelyezkedő spinalis vagy suprapontin károsodás esetén keletkezik és többnyire spasztikus jellegú hólyag és záróizom múködési zavarokkal járhat. Az alsó motoneuron lézió esetén a sacralis vizelési központban, vagy annak szintje alatt helyezkedik el az idegrendszeri károsodás és petyhüdt, funkciózavarok észlelhetők. A spasztikus alsó húgyúti funkciózavarra jellemző a detrusor-túlmúködés és a következményes vizeletinkontinencia, amely gyakran detrusor sphincter disszinergiával együttesen jelentkezik. Ebben az esetben az akaratlan vizeletvesztés mellett vizeletretenció is jelentkezik. A spasztikus típusú hólyagfunkció-zavar legveszélyesebb formáiban magasnyomású (detrusor nyomás a tárolási szakaszban 40 vízcm fölé emelkedik) vagy csökkent tágulékonyságú (compliance $20 \mathrm{ml} /$ vízcm alatti) és kapacitású hólyagmúködés alakul ki, amely a következményes vesicoureteralis reflux megjelenése miatt a felső húgyutak károsodásához és visszatérő húgyúti infekciók fellépéséhez vezethet. A károsodás lehet részleges vagy teljes, érintheti a szenzoros, vegetatív és a motoros beidegzést is. A felső és az alsó motoneuron lézió tünetei ugyancsak kombinálódhatnak. A fentiek alapján nagyon változatos klinikai kép jöhet létre. Az egyik legtípusosabb esetben, pl. teljes gerincvelői harántsérülés esetén, automata reflexhólyag alakul ki. Ennek lényege, hogy a hólyag bizonyos térfogat elérésekor, automatikusan összehúzódik, a vizelet pedig akadálytalanul kiürül, anélkül, hogy a beteg a hólyagtelődés és a vizeletürítés érzetéről tudatosulna. A petyhüdt típusú funkciózavar általában detrusor areflexiához és petyhüdt medencefenék kialakulásához vezet, amely vizeletretenció és neurogén eredetű stresszinkontinencia képében jelenik meg (3).

A funkcionális alapon történő felosztásra legjobban alkalmazható a Madersbacher-féle funkcionális beosztás (1. ábra). Ennek lényege, hogy a hólyag, illetve az urethralis sphincter múködését jellemezzük normális funkció, túlmúködés és alulmúködés szerint, amelyek kombinációkban is előfordulhatnak (4).

Pontos statisztikai adatok nem állnak rendelkezésünkre a hazai esetszámokat illetően, azonban a neurológiai kórképekben előforduló alsó húgyúti funkciózavarok gyakoriságával kapcsolatban ismeretesek útmutató adatok (5). Az agyi daganatok esetében 24\%-ban észleltek neurogén hólyagmúködést. Az idősebb kor is hajlamosít hólyagfunkció zavarra, a demencia súlyossági fokától függően 30-100\%-ban állapítottak meg NLUTD-t. Agyi érbetegségek 20-50\%-ában, sclerosis multiplexben 52-97\%-ban (vizeletürítési zavar: 37-72\%, inkontinencia: 33-52\%) találtak neurogén hólyagmúködésre utaló eltérést. Meningomyelocele esetén szinte minden esetben kialakul funkciózavar (90-97\%), amely az esetek felében detrusor sphincter disszinergiával (DSD) társul. A cukorbetegek felében fejlődik ki perifériás neuropathia és e betegek több mint háromnegyedében vizelettartás és ürítési problémák is jelentkeznek (5). A kismedencei mútétek közül az abdominoperinealis rectum exstirpációt követően az esetek felében, radikális hysterectomia után 8-57\%-ában alakul ki NLUTD. A gerincsérülés gyakorisága külföldi adatok alapján 40/1 000000 fő, akiknél 80\%-ban alakul ki következményes húgyhólyagfunkció-zavar (6). A fenti számokból jól kitúnik, hogy relatív gyakori problémáról van szó, amelyet sajnos sokszor nem, vagy nem kelló időben észlelünk.

A NLUTD-s betegek kezelésének, gondozásának elsődleges célja a vesefunkció megőrzése az alacsony tárolási és ürítési húgyhólyagnyomás biztosításával. Ez érthető, hiszen a gerincvelősérültek vezető haláloka sokáig a veseelégtelenség volt (7). A diagnosztikai és az ezzel együtt járó terápiás késlekedés súlyos szövődmények kialakulásával jár. Az antibiotikumok bevezetésével, illetve az intermittáló önkatéterezés technikájának elterjedésével drámaian csökkent az ezen betegeknél regisztrált életveszélyes (UTI, veseelégtelenség) szövődmények száma (8). Jelenleg a detrusor izomzat relexációjához vezető anticho-

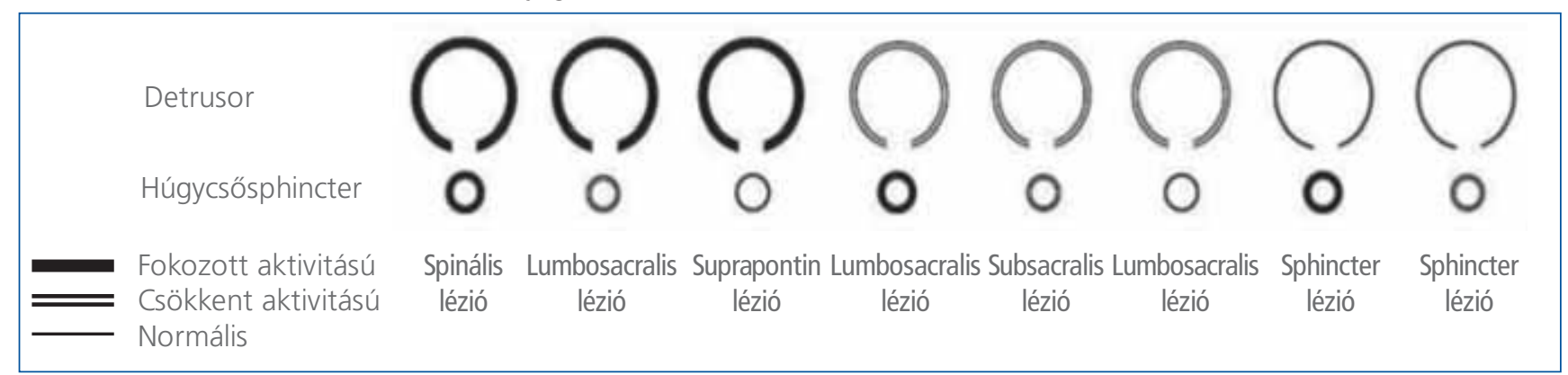

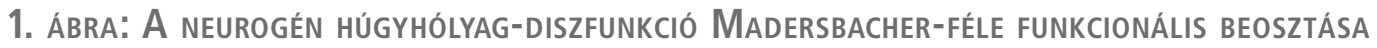


linerg gyógyszerek és az intermittáló önkatéterezés (CIC) jelentik a neurogén detrusor túlmúködés elsővonalbeli kezelésének alapjait. A neurogén eredetű detrusor areflexia elsővonalbeli kezelésében jelentős szerep jut az intermittáló önkatéterezésnek (9). A konzervatív kezelés sikertelensége esetén másodvonalban, a hólyagnyomás csökkentésére, a tágulékonyság és a kapacitás növelésére botulinum toxin intradetrusor injekciót alkalmazhatunk. Eredménytelenség esetén sebészi ellátás válhat szükségessé, amely során a húgyhólyag augmentációját végezzük, ezzel biztosítva a megfelelő tároló kapacitást, illetve az alacsony hólyagnyomást (10, 11). A leggyakrabban vékonybél (ileum) szakasszal történik a hólyagfal augmentációja. A posztoperatív időszakban tapasztalt magas kontinencia arány, megnövekedett húgyhólyag-kapacitás és csökkent maximális detrusor tárolási nyomás mind a sikeres mútéttechnika és a magas betegelégedettség mellett szólnak (12).

\section{Betegek és módszer}

Klinikánkon egy 23 éves (2011. október) és egy 28 éves (2015. szeptember) nőbetegnél végeztünk terápiarezisztens neurogén húgyhólyag-diszfunkció miatt nyílt húgyhólyag-augmentációt. A betegeinknél vizeletvizsgálatot, ultrahangvizsgálatot, cystometria és nyomás-áramlás vizsgálatokat, refluxvizsgálatot végeztünk a preoperatív és posztoperatív időszakban. Mindkét esetben veleszületett gerincfejlődési rendellenességek (kongenitális sacrum agenesia, illetve meningomyelocele) képezték a neurogén húgyhólyag-diszfunkció alapját. Bár a betegek intermittáló önkatéterezést végeztek akontratkilis hólyagjuk miatt, a neurogén hólyagfunkció-zavar progressziója a húgyhólyag compliance csökkenéséhez, következményes zsugorhólyag, vesico-ureteralis reflux és veseüregrendszeri tágulat kialakulásához, illetve recidív húgyúti infekciók megjelenéséhez vezetett. Egy esetben vesicoureterális reflux (VUR) talaján kialakult hydronephrosis és afunkciós vesemúködés miatt korábban bal oldali nephrectomia történt. Mindkét betegnél előfordult vizeletinkontinencia a katéterezések között, a kis hólyagkapacitás miatt. A mútéti indikációt mindkét esetben a kifejezetten beszúkült compliance (2,6, illetve 4,7 m/vízcm, illetve $7 \mathrm{ml}$ vízcm) és az alacsony húgyhólyag-kapacitás (160, illetve 220 $\mathrm{ml}$ ) értékek jelentették. A betegek preoperatív és posztoperatív státuszát az 1. táblázatban foglaltuk össze. A konzervatív (anticholinergicum + ClC) és minimál invazív (botox intradetrusor injekció) terápia hatástalansága miatt mindkét betegnél húgyhólyag-augmentáció történt kirekesztett, detubularizált ileumszakasz felhasználásával. A mútét során a terminális ileum 40-50 cm-es szakaszát hosszában felvágtuk és U-alakban összehajtottuk majd összevarrtuk, mintegy sapkát képezve. A hólyagfal-reszekciót mindig a trigonum szintje felett végeztük, tehát az eredeti hólyag nagyobbik felét eltávolítottuk, majd az így kapott béleredetű "félhólyagot" a cranialis feléhez anasztomizáltuk (2-3. ábra). Ügyeltünk arra, hogy megfelelő hosszúságú bélszakasz maradjon, amely elegendő a $\mathrm{B}_{12}$-vitamin felszívódásához (13). A betegek preoperatív klinikai paramétereit az 1. táblázat tartalmazza.

\section{1. tÁblÁzAT: A BETEGEK PRE- ÉS POSZTOPERATíV KLINIKAI} PARAMÉTEREI

\begin{tabular}{|c|c|c|}
\hline Klinikai paraméterek & 1. beteg & 2. beteg \\
\hline Életkor (év) & 29 & 25 \\
\hline Jtánkövetés (hó) & 85 & 27 \\
\hline $\begin{array}{l}\text { UTI száma/év } \\
\text { (preop. - posztop.) }\end{array}$ & $4 / 0$ & $5 / 0$ \\
\hline $\begin{array}{l}\text { 〈reatinin ( } \mu \mathrm{mol} / \mathrm{l}) \\
\text { (preop. - posztop.) }\end{array}$ & $101 / 88$ & $98 / 78$ \\
\hline GFR (preop. - postop.) & $>60 />60$ & $>60 />60$ \\
\hline $\begin{array}{l}\text { Vese UH } \\
\text { (preop. - posztop.) }\end{array}$ & $\begin{array}{l}\text { egyoldali Gr II } \\
\text { tágulat/nincs } \\
\text { tágulat }\end{array}$ & $\begin{array}{l}\text { jelzett } \\
\text { tágulat/nincs } \\
\text { tágulat }\end{array}$ \\
\hline $\begin{array}{l}\text { Vizeletinkontinencia száma/ } \\
\text { nap (preop. - posztop.) }\end{array}$ & $5 / 0$ & $5 / 0$ \\
\hline $\begin{array}{l}\text { Húgyhólyagkapacitás (ml) } \\
\text { (preop. - posztop.) }\end{array}$ & $\begin{array}{l}160 \text { *349 } \\
\text { *VUR nélkül } \\
\text { cisztográfia } \\
\text { során mérve }\end{array}$ & $239 / 451$ \\
\hline $\begin{array}{l}\text { Compliance (ml/vízcm) } \\
\text { (preop. - postop.) }\end{array}$ & $7,5 / 26,5$ & $4,7 / 29$ \\
\hline $\begin{array}{l}\text { Maximális detrusor nyomás } \\
\text { (vízcm), (preop. - postop.) }\end{array}$ & $74 / 16$ & $75 / 17$ \\
\hline VUR (preop. - posztop.) & $\mathrm{I} / \mathrm{N}$ & $\mathrm{l} / \mathrm{N}$ \\
\hline
\end{tabular}

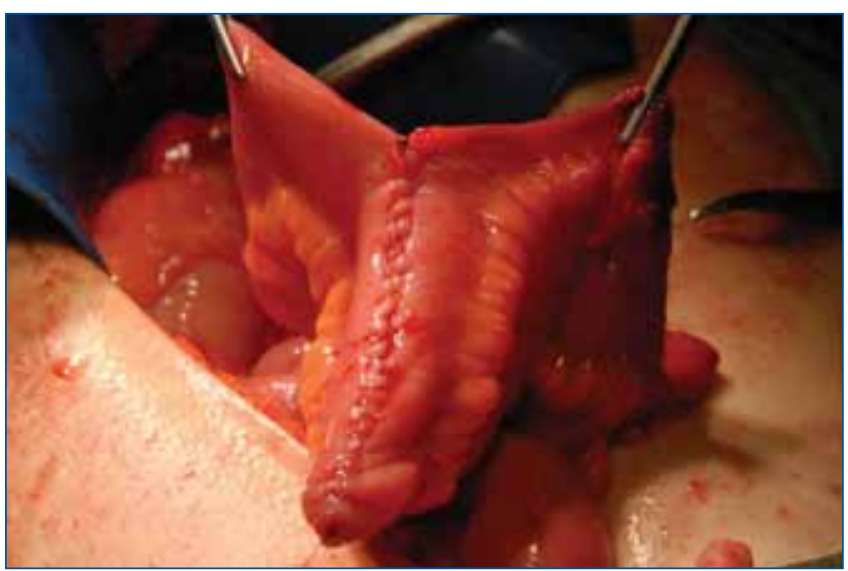

\section{2. ÁBRA: A DETUBULARIZÁLT, SAPKASZERÜEN ÖSSZEVARRT} ÉS AUGMENTÁCIÓRA ELŐKÉSZÍTETT ILEUMSZAKASZ

\section{Eredmények}

A posztoperatív időszakban jelentős komplikációt nem észleltünk. Az állandó katéter eltávolítása után a betegek visszatértek intermittáló önkatéterezési technikájukhoz. 
SzÖvettani vizsgálattal a hólyagfal fibrotikus átalakulása igazolódott mindkét esetben. A betegeknél mútét után megszúntek a húgyúti fertőzések, a katéterezések közötti akaratlan vizeletvesztések, és az anticholinerg kezelést elhagyhattuk. Jelenleg 85 és 27 hónapos utánkövetés során mindkét beteg kontinens és intermittáló önkatéterezéssel (napi 5xCIC) ürítik vizeletét. Mindkét esetben szignifikánsan nőtt a húgyhólyag-kapacitás (1. beteg:160 ml IVUR nélkül!] vs. 349 ml; 2. beteg: 221 ml vs. $451 \mathrm{ml}$ ), a compliance (1. beteg: 7,5 m/vízcm vs. 26,5 m/vízcm; 2. beteg: 2,6-4,7 m/vízcm vs. 29 m/vízcm) és csökkent a maximum detrusor nyomás a preoperatív értékekhez képest (1. beteg: 74 vízcm vs. 16 vízcm; 2. beteg: 75 vízcm vs. 17 vízcm) (4-6. ábra). A növekvő hólyagkapacitás és tágulékonyság mellett javuló vesefunkciót és csökkenő veseüregrendszeri tágulatot tapasztaltunk. A metabolikus eltéréseket jelen dolgozatunk nem vizsgálta, azonban a betegeinknél is történt posztoperatív rendszeres Astrup és ionkontroll, illetve lelettől függően sav-bázis egyensúly korrigálása. A betegek posztoperatív klinikai paramétereit az 1. táblázat mutatja.

\section{Megbeszélés}

Mikulicz volt az első 1899-ben, aki vékonybélpótlással próbálkozott a húgyhólyag nagyobbítására, majd Yeates detubularizált vékonybélszakaszt használt fel, amely a bélhólyag rezervoárok kialakításának azóta is bevált módszere (14). A fordulópontot az intermittáló önkatéterezés (CIC) elterjedése jelentette (15), ezt követően számos augmentációs technika került bevezetésre, különböző bélrendszeri pótlásokkal. A gyermekurológiában gyomor, vastagbél és vékonybél felhasználásával is végeznek húgyhólyag-augmentációt, amelyről számos hazai közlemény is született $(16,17)$. Az általunk detubularizált ileumszakasszal végzett augmentációs cisztoplasztikákat követően nőtt a hólyagkapacitás és a compliance, illetve csökkent a tárolási nyomás. A mútéteket követően mindkét beteg kontinenciája javult, a húgyúti fertőzések száma csökkent, a húgyhólyagjukat továbbra is intermittáló katéterezéssel ürítik. A saját tapasztalataink megfelelnek a nemzetközi irodalomban található adatoknak, amelyek szerint az átlagos hólyagkapacitás növekedés eléri a 300-450 ml-t, illetve az átlagos maximális detrusor nyomás csökkenés a 20 vízcm-t (10). A hólyagkapacitás növelésének legfontosabb feltétele a megfelelő hoszszúságú ileumszakasz reszekciója. Általánosságban augmentáció céljára 50-60 cm-t javasolnak (11, 12). A túlságosan nagy reszekció a bél felszívó funkciójának csökkenéséhez és így hasmenés kialakulásához vezethet. A kontinencia javulása összefüggést mutat a NLUTD súlyosságával (12). Betegeinknél a kontinencia javítása érdekében további sebészi beavatkozásra nem volt szükségünk, azonban az irodalomban gyakran említenek a primer mútétet követő músphincter vagy TOT-szalag beültetéseket. A nemzetközi irodalomban szövődményként leggyakrabban a bélmúködési zavarok, hasmenés, ileus és hólyagkövesség szerepelnek (13). Esetünkben az egyik beteg panaszol hasmenést, amely javuló tendenciát mutat. A folyamatos bakteriuria és mucus termelés kedvez a húgyúti kövek kialakulásának, azonban a rendszeresen végzett intermittáló önkatéterezéssel ez többnyire megelőzhető. Az augmentált húgyhólyag cisztoszkópos ellenőrzése csak 10 év után ja-

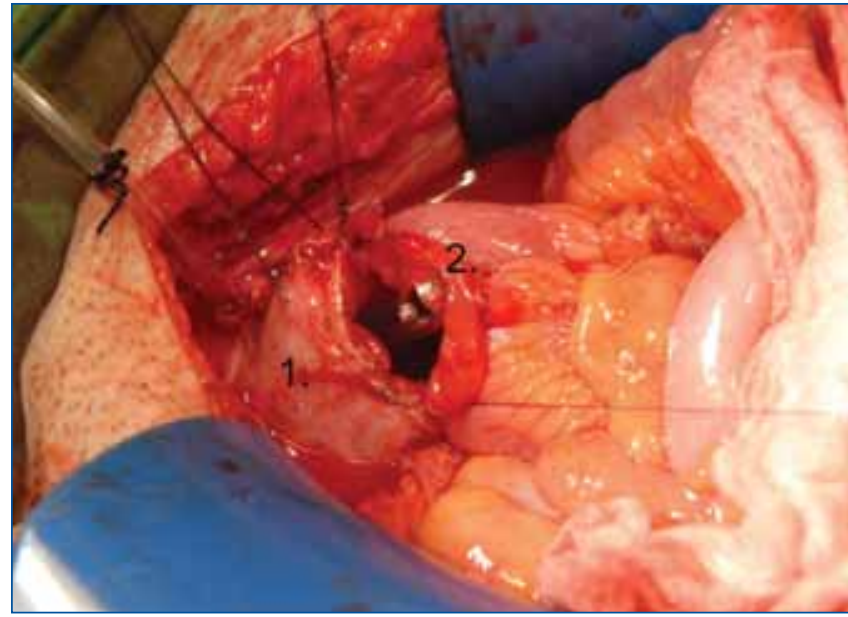

3. ÁBRA: HúgYhÓlYAg-AUgmentÁCIÓ: 1 - húgYhÓLYAG, 2 - U-ALAKBAN EGYEZTETETT ILEUMSZAKASZ

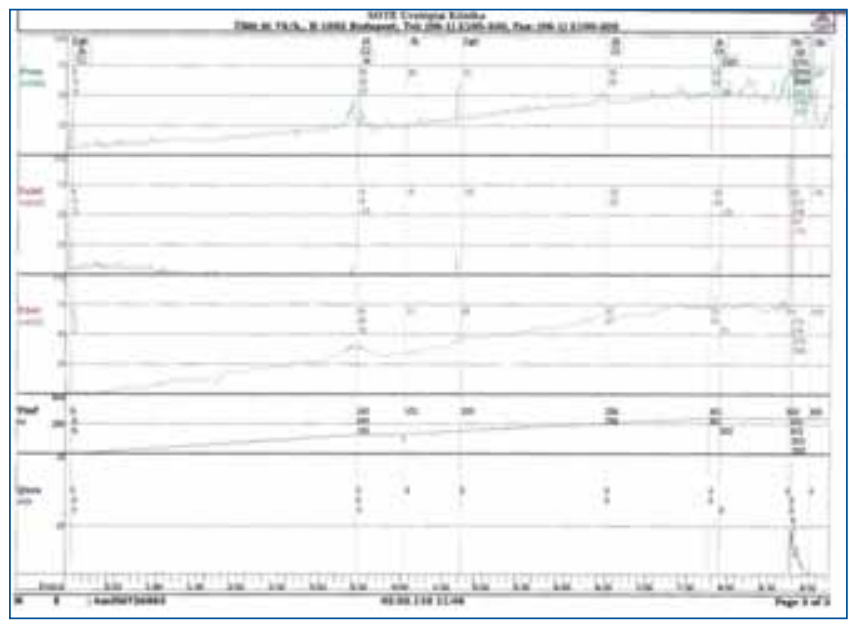

4. Ábra: Preoperatív urodinamikai vizsgálat

(1. BETEG): KIFEJEZETTEN BESZÜKÜLT COMPLIANCE, MAGAS TÁROLÁSI NYOMÁS

vasolt. A mútétet követően a reziduális hólyagfal mennyiségétől és az augmentációra használt bélszakasz hosszától függően szükség lehet a további detrusor relaxációs kezelésre (orális anticholinergikumok, intravesicalis botulinum toxin injekció). Esetünkben mútét után mindkét beteg elhagyta a korábbi anticholinerg kezelést (13). Fontos, hogy az augmentációt idejében, még a tartós vesekárosodás bekövetkezése előtt elvégezzük. Ugyanakkor gyermekeknél a növekedést figyelembe véve az a legszerencsésebb, ha 16 éves életkorig el tudjuk halasztani a mútét időpontját (16, 17).

\section{Következtetés}

A neurogén hólyagmúködési zavar súlyos, életet veszélyeztető következménye lehet a VUR okozta recidív húgyúti infekció és veseelégtelenség. Amennyiben konzervatív kezelés 


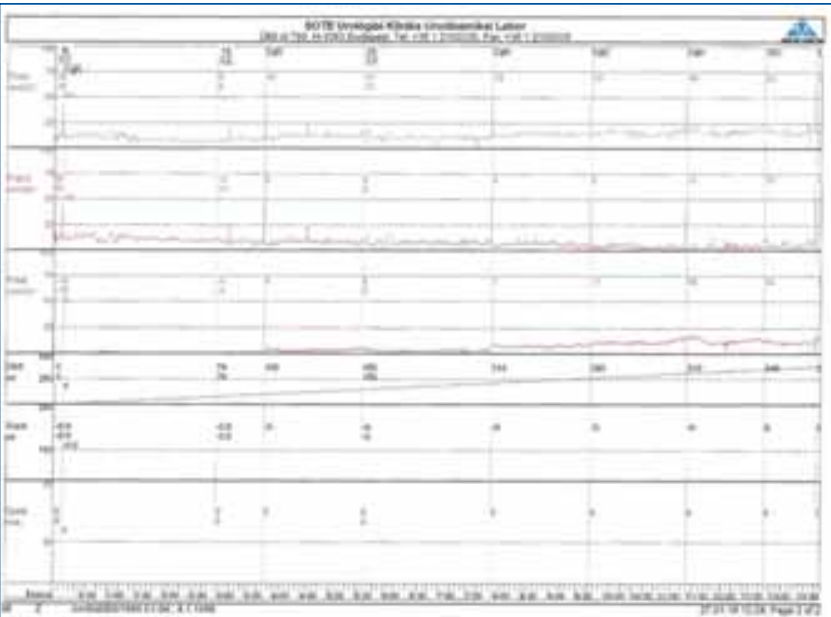

\section{5. Ábra: Posztoperatív UROdinamikal VIzsgálat} (1. beteg). A hólyagkapacitás 350 ml Feletti, a TÁGULÉKONYSÁG PEDIG SZINTÉN NORMÁLIS TARTOMÁNYBA KERÜLT (C>20 ML/VÍZCM), A TÁROLÁSI NYOMÁS ALACSONY

segítségével nem sikerül a húgyhólyag nyomását, compliance-jét, kapacitását a normáltartományban tartani, akkor a húgyhólyag bélszakasszal történő augmentációját javasolt elvégezni, mert ez megőrizheti és/vagy javithatja a beteg vesefunkcióját, csökkentheti a visszatérő lázas húgyúti fertőzések számát és így megóvhatja a beteg életét. Ezen kívül a beteg életminőségét is javítja, hiszen a katéterezések közötti kontinencia is javul.

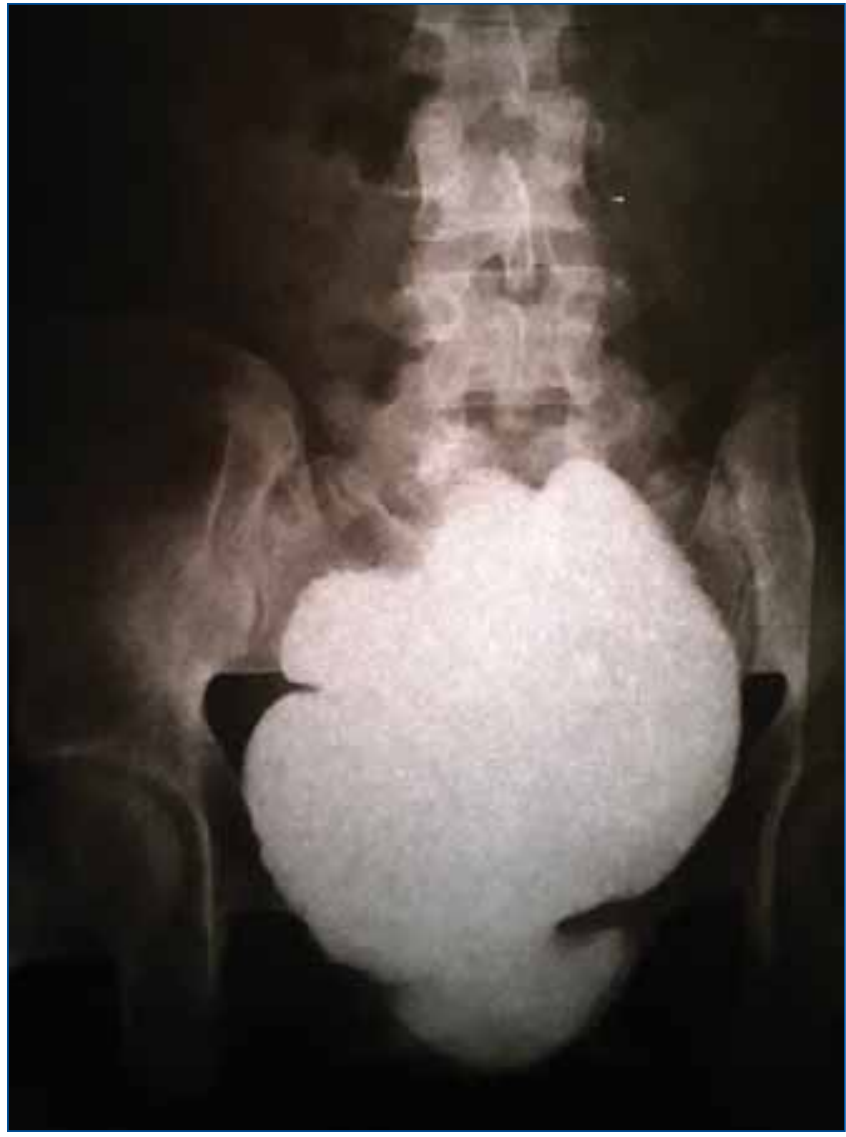

6. Ábra: Posztoperatív cisztográfiás felvétel: Jó HÚGYHÓLYAG-KAPACITÁS, VUR NÉLKÜL

\section{Irodalom}

1. Stöhrer M, Castro-Diaz D, Chartier-Kastler E, et al. EAU Guidelines on Neurogenic Lower Urinary Tract Dysfunction. European Urology 2009; 56: 81-88. https://doi.org/10.1016/j.eururo.2009.04.028

2. Biers SM, Venn SN, Greenwell TJ. The past, present and future of augmentation cystoplasty. BJU Int 2012; 109: 1280-93. https://doi. org/10.1111/.1464-410X.2011.10650.x

3. Wyndaele J-J. The management of neurogenic lower urinary tract dysfunction after spinal cord injury. Nature Reviews Urology 2016; 13: 705-714. https://doi.org/10.1038/nrurol.2016.206

4. Madersbacher $\mathrm{H}$. The various types of neurogenic bladder dysfunction: an update of current therapeutic concepts. Paraplegia 1990; 28: 217-29. https://doi.org/10.1038/sc. 1990.28

5. Majoros A, Hamvas A, Romics I. Neurogén eredetủ hólyagmüködési zavarok. Magyar Urológia Irányelvei 2009; 15-23.

6. Randy A. Vince, Adam P. Klausner. Surveillance Strategies for Neurogenic Lower Urinary Tract Dysfunction. Urologic Clinics of North America 2017; 44(3): 367-375.

7. Majoros A. Az inkontinencia konzervatív kezelése. Orvosi Hetilap 2005; 146(49): 2509-11.

8. Perovic SV, Vukadinovic VM, Djordjevic ML. Augmentation ureterocystoplasty could be performed more frequently. J Urol 2000; 164: 924-7. https://doi.org/10.1097/00005392-200009020-00003 https://doi. org/10.1016/50022-5347(05)67219-9

9. Krebs J, Bartel P, Pannek J. Functional outcome of supratrigonal cystectomy and augmentation ileocystoplasty in adult patients with refractory neurogenic lower urinary tract dysfunction. Neurourol Urodyn 2016; 35: 260-266. https:/doi.org/10.1002/nau.22709
10. Majoros A. A vizeletelvezetés lehetőségei neurogén eredetú hólyagmúködési zavarok esetén. Rehabilitáció 2012; 22: 35-39.

11. Gobeaux N, Yates DR, Denys P, et al. Supratrigonal cystectomy with Hautmann pouch as treatment for neurogenic bladder in spinal cord injury patients: long-term functional results. Neurourol Urodyn 2012; 31: 672-6. https:/doi.org/10.1002/nau.21239

12. Gurung PM, Attar KH, Abdul-Rahman A, et al. Long-term outcomes of augmentation ileocystoplasty in patients with spinal cord injury: A minimum of 10 years of follow-up. BJU Int 2012; 109: 1236-42. https:// doi.org/10.1111/.1464-410X.2011.10509.x

13. Pannek J, Haupt G, Schulze $H$, et al. Influence of continent ileal urinary diversion on vitamin B12 absorption. J Urol 1996; 155: 1206-8. https:// doi.org/10.1097/00005392-199604000-00014 https://doi.org/10.1016/ S0022-5347(01)66217-7

14. Yeates WK. A technique of ileocystoplasty. Br J Urol 1956; 28: 410.

15. Lapides J, Diokono AC, Silber SJ, et al. Clean intermittent self-catheterization in the treatment of urinary tract disease. J Urol 1972; 107: 458-61. https://doi.org/10.1016/50022-5347(17)61055-3

16. Kispal Z, Balogh D, Erdei O, et al. Complications after bladder augmentation or substitution in children: a prospective study of 86 patients. BJU Int. 2011; 108(2): 282-9. https://doi.org/10.1111/.1464410X.2010.09862.x

17. Juhasz Z, Somogyi R, Vajda P, et al. Does the type of bladder augmentation influence the resolution of pre-existing vesicoureteral reflux? Urodynamic studies. Neurourol Urodyn. 2008; 27(5): 412-6. https://doi. org/10.1002/nau.20529 